\title{
$\mathrm{DEL}$ 적혈구에 의한 항-D 동종면역
}

\author{
김경희 ${ }^{1} \cdot$ 김경은 $^{1} \cdot$ 우광숙 $^{1} \cdot$ 한진영 $^{1}$ · 김정만 ${ }^{1} \cdot$ 박경운 $^{2}$ \\ 동아대학교 의과대학 진단검사의학교실', 서울대학교 의과대학 검사의학교실
}

\section{Primary anti-D Immunization by DEL Red Blood Cells}

\author{
Kyeong-Hee Kim, M.D. ${ }^{1}$, Kyung-Eun Kim, M.D. ${ }^{1}$, Kwang-Sook Woo, M.D. ${ }^{1}$, Jin-Yeong Han, M.D. ${ }^{1}$, Jeong-Man Kim, M.D. ${ }^{1}$, \\ and Kyoung Un Park, M.D. ${ }^{2}$ \\ Department of Laboratory Medicine', Dong-A University College of Medicine, Busan; Department of Laboratory Medicine², \\ Seoul National University College of Medicine, Seoul, Korea
}

\begin{abstract}
Extremely weak $D$ variants called DEL are serologically detectable only by adsorption-elution techniques. A nucleotide change of exon 9 in $R H D$ gene, $R H D(K 409 \mathrm{~K}, 1227 \mathrm{G}>\mathrm{A})$ allelic variant is present in almost all the DEL individuals of East Asians. No DEL phenotype has yet been shown to induce a primary alloanti-D immunization in East Asia. A 68-yr-old D-negative Korean man was negative for anti-D at admission, and he developed alloanti-D after transfusion of red blood cells (RBC) from 4 apparently D-negative donors. Four donors who typed D-negative by routine serologic test were analyzed by real-time PCR for $R H D$ gene and $R H D$ (K409K). One donor was found to have $R H D(\mathrm{~K} 409 \mathrm{~K})$. This is the first case in which DEL RBCs with $R H D(\mathrm{~K} 409 \mathrm{~K})$ induced a primary alloanti-D immunization in Asian population. Because the DEL phenotype can induce an anti-D immunization in D-negative recipients, further discussion is needed whether RhD negative donors should be screened by molecular method and what an efficient genotyping method is for detecting the $R H D$ gene carriers in Korea. (Korean J Lab Med 2009;29:361-5)
\end{abstract}

Key Words : RHD, DEL RBC, Anti-D antibody, Alloimmunization

\section{INTRODUCTION}

Anti-D immunization may cause hemolytic transfusion reactions and hemolytic disease of the newborn. For the transfusion recipient who has D-negative red blood cells (RBC), D antigen-negative blood units should be given. The frequency of D-negative varies widely among differ-

Received: March 17, 2009

Manuscript No : KJLM09-043

Revision received: May 27, 2009

Accepted: June12, 2009

Corresponding author: Kyeong-Hee Kim, M.D.

Department of Laboratory Medicine, Dong-A University College of Medicine, 1 Dongdaesindong 3-ga, Seo-gu, Busan 602-103, Korea Tel : +82-51-240-2850, Fax : +82-51-255-9366

E-mail : progreen@dau.ac.kr ent ethnic groups. Fifteen percent of Caucasian populations, 3 to 7 percent of African populations and only 0.5 percent of Chinese and Japanese populations are D-negative phenotype [1-4].

The D-negative frequency in Korean persons is 0.15 percent, about 1/100th of that in Caucasian individuals [5]. Recently the molecular basis of D-negative in Korean donors was characterized by two separate studies [6, 7]. Among Korean D-negative persons, nearly three-fourths showed RHD total deletion, 13 to 16 percent had RHD (K$409 \mathrm{~K})$ allele, and 9 to 10 percent had the RHD-CE-D hybrid form. RHD (K409K, 1227G>A) allelic variant, a substitution of the last nucleotide of exon 9 in RHD gene, has 
DEL phenotype and most DEL donors are typed as D-negative because routine serologic typing does not distinguish D-negative from the DEL phenotype. According to the national transfusion guidelines of many other countries, RBCs from persons with the DEL phenotype are not differentiated from truly D-negative and therefore are used as D-negative blood for D-negative recipients. So far, two cases of anti-D immunization by DEL red blood cells have been reported in Austria and Japan [8, 9]. This report describes a case of primary anti-D immunization induced by transfusion of RBCs from a Korean donor with DEL phenotype, carrying $R H D$ (K409K) allele.

\section{CASE REPORT}

\section{Immunohematology}

A 68-yr-old group O, D-negative (ce) Korean man was admitted to Dong-A University Hospital for operation of atherosclerosis of abdominal aorta. He received 2 units of crossmatch-compatible group O, D-negative RBC during an aortobifemoral bypass surgery on February 21, 2008. He had no history of prior transfusions or transplantations. Antibody screening test before the transfusion was negative (ID-DiaCell I+II, DiaMed AG, Cressier, Morat, Switzerland). Additionally, he received 2 units of crossmatch-compatible group $\mathrm{O}, \mathrm{D}$-negative RBC because of low hemoglobin level on day 5 post-operation. On March 6,2008 , the antibody screening became positive and antiD was identified in the patient's serum by gel technique (ID-DiaPanel \& ID-DiaPanel-P, DiaMed AG). The autologous control was negative. There was no evidence of acute or delayed hemolytic transfusion reactions after those transfusions and no remarkable changes in the levels of hemoglobin, indirect bilirubin, and lactate dehydrogenase.

The anti-D developed 9 days after last RBC transfusion in the recipient was unexplained, so analytical checks for errors including sample labeling, patient and donor units identification as well as transfusion procedure were performed. Indication of an error was not detected. He did not receive Rh immunoglobulin. Forty days later the pati- ent's anti-D was persistently detected and showed similar strength of agglutination.

\section{Molecular biology}

Stored blood samples transfused on Feb 26 were used to confirm the status of RHD gene at the molecular level. The blood samples transfused on Feb 21 were not available for molecular study because the documented interval for storage of those samples was outdated. For these 2 units of RBC, we investigated RHD gene analysis using plasma stored in Korean Red Cross. Informed consent was obtained from the patient for the RHD genotype analysis.

DNA was isolated from plasma or peripheral blood with QIAamp blood mini kit (QIAGEN, Hilden, Germany). RHD genes were determined by real-time PCR using the LightCycler 2.0 (Roche, Penzberg, Germany).

\section{1) Detection of intron 4 and exon 7 by real-time PCR}

Plasma from 4 donors and peripheral blood from the patient were examined for the presence of $R H D$-specific polymorphisms located in RHD intron 4 and $R H D$ exon 7 by real-time PCR and samples negative in these real-time PCR tests were further tested for the RHD promoter region and $R H D$ exon 10. Negative results were interpreted as the complete deletion of $R H D$ gene. The real-time PCR procedures for RHD intron 4 and RHD exon 7 were as follows: $50 \mathrm{ng}$ of DNA template mixed together with $2 \mu \mathrm{L} \mathrm{LC}$ FastStart DNA Master SYBR Green I (Roche, Penzberg, Germany), $0.4 \mu \mathrm{M}$ each primer (Table 1), and $3.0 \mathrm{mM} \mathrm{MgCl}_{2}$ in a final volume of $20 \mu \mathrm{L}$. The following PCR program was used: $10 \mathrm{~min}$ at $95^{\circ} \mathrm{C}$ and 33 cycles of $5 \mathrm{sec}$ at $95^{\circ} \mathrm{C}$, $3 \mathrm{sec}$ at $58^{\circ} \mathrm{C}$, and $10 \mathrm{sec}$ at $72^{\circ} \mathrm{C}$. The program for analytical melting was $5 \mathrm{sec}$ at $95^{\circ} \mathrm{C}$ and $30 \mathrm{sec}$ at $65^{\circ} \mathrm{C}$ and an increase to $99^{\circ} \mathrm{C}$ at a $0.2^{\circ} \mathrm{C}$ per second ramp rate. The melting temperature $(\mathrm{Tm})$ for intron 4 was $87.0 \pm 0.5^{\circ} \mathrm{C}$ and that of exon 7 was $86.5 \pm 0.5^{\circ} \mathrm{C}$.

2) Detection of promoter region and exon 10 by real-time PCR

The real-time PCR procedure for promoter region was 
Table 1. Primers used for RHD gene real-time PCR

\begin{tabular}{lclc}
\hline Name & Genomic region & \multicolumn{1}{c}{ Sequence $\left(5^{\prime}-3^{\prime}\right)$} & Reference \\
\hline e4F & Intron 4 & CCTATITGGGCTGTACTGTGG & {$[10]$} \\
Di4R & Intron 4 & GAACCTGCTCTGTGAAGTGCT & {$[10]$} \\
De7F & Exon 7 & TGTTGTACCGAGTGC & {$[11]$} \\
De7R & Exon 7 & ACCATGCCATTGCCG & {$[11]$} \\
PRM-F & Promoter & TCCACTICCACCTCCCTGC & {$[12]$} \\
& region & & \\
PRM-R & Promoter & GCAGCCAACTTCCCCTGTG & {$[12]$} \\
& region & & \\
De10-3F & Exon 10 & TAAGCAAAAGCATCCAA & {$[11]$} \\
De10-3R & Exon 10 & ATGGTGAGATTCTCCT & {$[11]$} \\
\hline
\end{tabular}

as follows: 50 ng of DNA template mixed together with 2 $\mu \mathrm{L}$ LC FastStart DNA Master SYBR Green, $0.3 \mu \mathrm{M}$ each primer (Table 1), $1 \mu \mathrm{L} \mathrm{10 \%} \mathrm{dimethyl} \mathrm{sulfoxide} \mathrm{(DMSO),} \mathrm{and}$ $3.0 \mathrm{mM} \mathrm{MgCl}_{2}$ in a final volume of $20 \mu \mathrm{L}$. The following PCR program was used: $10 \mathrm{~min}$ at $95^{\circ} \mathrm{C}$ and 33 cycles of $3 \mathrm{sec}$ at $95^{\circ} \mathrm{C}, 2 \mathrm{sec}$ at $60^{\circ} \mathrm{C}$, and $10 \mathrm{sec}$ at $72^{\circ} \mathrm{C}$. The program for analytical melting was $5 \mathrm{sec}$ at $95^{\circ} \mathrm{C}$ and $15 \mathrm{sec}$ at $65^{\circ} \mathrm{C}$ and an increase to $99^{\circ} \mathrm{C}$ at a $0.2^{\circ} \mathrm{C}$ per second ramp rate. The Tm for promoter region was $82.5 \pm 0.5^{\circ} \mathrm{C}$. The real-time PCR procedure for exon 10 was as follows: $50 \mathrm{ng}$ of DNA template mixed together with $2 \mu \mathrm{L}$ LC FastStart DNA Master SYBR Green I, $0.4 \mu \mathrm{M}$ each primer (Table 1), and $4.0 \mathrm{mM} \mathrm{MgCl}_{2}$ in a final volume of $20 \mu \mathrm{L}$. The following PCR program was used: $10 \mathrm{~min}$ at $95^{\circ} \mathrm{C}$ and 33 cycles of $5 \mathrm{sec}$ at $95^{\circ} \mathrm{C}, 5 \mathrm{sec}$ at $60^{\circ} \mathrm{C}$, and $10 \mathrm{sec}$ at $72^{\circ} \mathrm{C}$. The program for analytical melting was $5 \mathrm{sec}$ at $95^{\circ} \mathrm{C}$ and 30 sec at $65^{\circ} \mathrm{C}$ and an increase to $99^{\circ} \mathrm{C}$ at a $0.2^{\circ} \mathrm{C}$ per second ramp rate. The $\mathrm{Tm}$ for exon 10 was $84.5 \pm 0.5^{\circ} \mathrm{C}$.

\section{3) Detection of $R H D(K 409 K)$ by real time PCR}

A sample positive in RHD intron 4 and RHD exon 7 realtime PCR was further investigated for RHD (K409K) by real-time PCR. The real-time PCR procedure for RHD (K409K) was as follows: 50 ng of DNA template mixed together with $2 \mu \mathrm{L}$ LC FastStart DNA Master HybProbe $2 \mu \mathrm{L}$ (Roche, Penzberg, Germany), $0.3 \mu \mathrm{M}$ each primer (Table 2), $0.3 \mu \mathrm{M}$ each probe (Table 2), and $4.0 \mathrm{mM} \mathrm{MgCl}_{2}$ in a final volume of $20 \mu \mathrm{L}$. The following PCR program was used: $10 \mathrm{~min}$ at $95^{\circ} \mathrm{C}$ and 40 cycles of $5 \mathrm{sec}$ at $95^{\circ} \mathrm{C}, 10 \mathrm{sec}$ at $60^{\circ} \mathrm{C}$, and $10 \mathrm{sec}$ at $72^{\circ} \mathrm{C}$. The program for analytical melting was $30 \mathrm{sec}$ at $95^{\circ} \mathrm{C}$ and $2 \mathrm{~min}$ at $40^{\circ} \mathrm{C}$ and an increase
Table 2. Primers and probes for real-time PCR to detect the $R H D(\mathrm{~K} 409 \mathrm{~K})$

\begin{tabular}{|c|c|c|}
\hline Name & Reaction & Sequence $\left(5^{\prime}-3^{\prime}\right)$ \\
\hline RHK409-F & Primer & AAAATATGGAAAGCACCTCATGA \\
\hline RHK409-R & Primer & ATGGATTTGTTTCTCCTCTAGTT \\
\hline RHK409-D & Probe & $\begin{array}{l}\text { LC Red 640-ATCTTACCTTCCAGAAAA- } \\
\text { CTTGGTCATCAA-Phosphate }\end{array}$ \\
\hline RHK409-A & Probe & $\begin{array}{l}\text { CATGCACTCAAAATCTATCACGTTAATA- } \\
\text { GGTGAA-fluorescein }\end{array}$ \\
\hline
\end{tabular}

to $80^{\circ} \mathrm{C}$ at a $0.4^{\circ} \mathrm{C}$ per second ramp rate. The $R H D(\mathrm{~K} 409 \mathrm{~K})$ variant was analyzed by lower $\mathrm{Tm}$ of $61.5 \pm 0.5^{\circ} \mathrm{C}$ and wild type with higher $\mathrm{Tm}$ of $66.5 \pm 0.5^{\circ} \mathrm{C}$.

By real-time PCR analysis, one of four donors was found to have RHD (K409K) and the patient and three donors showed complete deletion of RHD gene. The blood positive for RHD (K409K) was transfused on February 26, 2008 and alloanti-D was detected after 9 days of transfusion.

\section{DISCUSSION}

The Rh blood group is the second most clinically significant antigen of the blood group system in human. It also is the most polymorphic of the blood groups with variations due to deletions or missense mutations. These molecular variations lead to reduced antigen density [13]. DEL is serologically designated as a quantitative variant of $\mathrm{D}$ antigen. A small amount of anti-D can be eluted from DEL red blood cells after incubation with anti-D, although there is no agglutination by the indirect antiglobulin test procedure of D typing. By molecular studies, DEL phenotype was expressed by several different mutations such as RHD (M295I, 885G>T), RHD (K409K, 1227G>A), RHD (IVS3+1G>A), RHD (IVS5-38del4), RHD (X418L), and RHD (delEx8) [8, 12, $14,15]$. These DEL variants can induce an alloanti-D in D-negative recipients because most DEL donors are typed as D-negative by serologic method. We could find two reports of anti-D alloimmunization in D-negative recipients after the transfusion of DEL variants. A 67-yr-old D-negative Japanese woman with a history of allosensitization to D antigen developed a secondary alloanti-D immunization induced by RHD (K409K) RBCs [9], and a 58yr-old D-negative Austrian woman developed a primary 
alloanti-D by another DEL variant, RHD (IVS5-38del4) [8]. In our case, interestingly, a 68-yr-old D-negative Korean man developed a primary alloanti-D by RHD (K409K) RBCs.

The molecular basis of D-negative is different among different ethnic populations. Most of D-negative Caucasian populations have complete RHD deletion but populations from China, Japan, and Korea have rather diverse mutation variants. The frequency of RHD (K409K, 1227G> A) allele in apparent D-negative Korean donors is about 13 to 16 percent, which is the most prevalent mutation variant for DEL phenotype in Korea [6, 7]. Recently, Taiwan researchers developed a real-time PCR-melting curve analysis to detect a nucleotide change at 1227 position of RHD exon 9. Since almost all the DEL type in East Asians have the characteristic 1227A mutation, this real-time PCR method for single nucleotide polymorphism showed high sensitivity (100\%) and high specificity (98.75\%) [16].

The routine $R H D$ genotyping in donor screening program was adopted in Germany and Upper Austria. Samples of first-time D-negative donors by serology were tested in pools of 20 for the RHD-specific polymorphic sites by PCR but the target sites of RHD gene were different in each country. Within 6 yr of testing, the prevalence of $R H D$ gene carriers detected was 0.21 percent and DEL phenotype was approximately one-half of the RHD gene carriers in Germany. Ninety-four samples of 23,330 pretyped D-negative samples carried at least one RHD marker in Upper Austria. These two studies suggested that the integration of $R H D$ genotyping into routine screening was practical and it would be necessary to adapt a proper RHD genotyping strategy in each population [17, 18]. Our report is the first case in which DEL RBCs with RHD (K409K) induced a primary alloanti-D immunization in Asian population. Because the DEL phenotype can induce an anti-D immunization in D-negative recipients, further discussion is needed whether D-negative donors should be screened by molecular method and what an efficient genotyping method is for detecting the RHD gene carriers in Korea.

\section{REFERENCES}

1. Daniels G. Human blood groups. 1st ed. Oxford: Blackwell Science 1995.

2. Lin-Chu M, Broadberry RE, Chang FJ. The distribution of blood group antigens and alloantibodies among Chinese in Taiwan. Transfusion 1988;28:350-2.

3. Mak KH, Yan KF, Cheng SS, Yuen MY. Rh phenotypes of Chinese blood donors in Hong Kong, with special reference to weak D antigens. Transfusion 1993;33:348-51.

4. Okuda H, Kawano M, Iwamoto S, Tanaka M, Seno T, Okubo Y, et al. The RHD gene is highly detectable in $\mathrm{RhD}$-negative Japanese donors. J Clin Invest 1997;100:373-9.

5. Hwang YS. Haplotype frequencies of Rh gene loci in Koreans. Korean J Blood Transfus 1996;7:233-40. (황유성. 한국인 Rh혈액형의 유전 자 일배체형 분석. 대한수혈학회지 1996;7:233-40.)

6. Kim JY, Kim SY, Kim CA, Yon GS, Park SS. Molecular characterization of D- Korean persons: development of a diagnostic strategy. Transfusion 2005;45:345-52.

7. Luettringhaus TA, Cho D, Ryang DW, Flegel WA. An easy RHD genotyping strategy for D- East Asian persons applied to Korean blood donors. Transfusion 2006;46:2128-37.

8. Wagner T, Körmöczi GF, Buchta C, Vadon M, Lanzer G, Mayr WR, et al. Anti-D immunization by DEL red blood cells. Transfusion 2005; 45:520-6.

9. Yasuda H, Ohto H, Sakuma S, Ishikawa Y. Secondary anti-D immunization by Del red blood cells. Transfusion 2005;45:1581-4.

10. Avent ND, Martin PG, Armstrong-Fisher SS, Liu W, Finning KM, Maddocks D, et al. Evidence of genetic diversity underlying Rh D-, weak $\mathrm{D}\left(\mathrm{D}^{\mathrm{u}}\right)$, and partial $\mathrm{D}$ phenotypes as determined by multiplex polymerase chain reaction analysis of the RHD gene. Blood 1997;89: 2568-77.

11. Aubin JT, Le Van Kim C, Mouro I, Colin Y, Bignozzi C, Brossard Y, et al. Specificity and sensitivity of RHD genotyping methods by PCRbased DNA amplification. Br J Haematol 1997;98:356-64.

12. Wagner FF, Frohmajer A, Flegel WA. RHD positive haplotypes in D negative Europeans. BMC Genet 2001;2:10.

13. Avent ND and Reid ME. The Rh blood group system: a review. Blood 2000;95:375-87.

14. Gassner C, Doescher A, Drnovsek TD, Rozman P, Eicher NI, Legler TJ, et al. Presence of RHD in serologically D-, C/E+ individuals: a 
European multicenter study. Transfusion 2005;45:527-38.

15. Richard M, Perreault J, Constanzo-Yanez J, Khalifé S, St-Louis M. A new DEL variant caused by exon 8 deletion. Transfusion 2007;47: 852-7.

16. Sun CF, Liu JP, Chen DP, Wang WT, Yang TT. Use of real time PCR for rapid detection of Del phenotype in Taiwan. Ann Clin Lab Sci 2008;38:258-63.
17. Flegel WA, von Zabern I, Wagner FF. Six years' experience performing RHD genotyping to confirm D- red blood cell units in Germany for preventing anti-D immunizations. Transfusion 2009;49:465-71.

18. Polin H, Danzer M, Gaszner W, Broda D, St-Louis M, Pröll J, et al. Identification of RHD alleles with the potential of anti-D immunization among seemingly D- blood donors in Upper Austria. Transfusion 2009;49:676-81. 